\title{
Study of Linkages Between Outward Foreign Direct Investment (OFDI) and Domestic Economic Growth: an Indian Perspective
}

http://doi.org/10.21272/fmir.3(1).43-49.2019

\author{
Anurag Agnihotri \\ Dr., Assistant professor, College of Vocational Studies, University of Delhi, India
}

\section{Shagun Arora}

Assistant Professor, New Delhi Institute of Management, India

\begin{abstract}
The inwards and outward FDI movement plays an important role in the economic development and growth of any economy. The OFDI have its impact on the home economy based on scale effect, competition effect and knowledge effect. It helps other domestic companies to expand their business and scale of firms by giving them technological and trade benefits. OFDI help the companies to improve efficiency and upgrade production processes. This paper is focusing on the Outward Foreign Direct investment (OFDI) and its linkage with the domestic growth in Indian perspective. It takes in to account various direct and indirect benefits which may spillover to domestic economy. This paper is examining the question whether OFDI is linked to production or it is regarded as a withdrawal of domestic capital. Further it has positive or negative impact on the GDP of the country. On the above question several studies have been conducted in developed countries but not in Indian context. So, this paper is attempting to answer the above question in Indian context. The research methodology for this paper is secondary in nature and the data collected for this paper is taken from the RBI sources. We have taken a period of 10 years from 2007 to 2016. For this paper, we used Augmented DickeyFuller (ADF) for testing the stationarity, Eigen value test, Trace test. Further we used the regression analysis in order to check the relationship of GDP and Outward Foreign Direct investment (OFDI). The results of the data analysis explain that there is no significant relationship between the OFDI and domestic economic growth in India. However, the results in case of some firms may not be the same.
\end{abstract}

Keywords: India, OFDI, Emerging Economy, Economic Implications, GDP.

JEL Classification: O 53, F21, F23.

Cite as: Agnihotri An., Arora Sh. (2019). Study of Linkages Between Outward Foreign Direct Investment (OFDI) and Domestic Economic Growth: an Indian Perspective. Financial Markets, Institutions and Risks, 3(1), 43-49. http://doi.org/10.21272/fmir.3(1).43-49.2019.

(C) The Authors, 2019. This article is published with open access at Sumy State University.

\section{Introduction}

Any developing country use OFDI to procure better technology, domestic supply, distribution network, managerial skills and competitiveness. The OFDI influence the economy based on scale effect, competition effect and knowledge effect. OFDI help the domestic companies to expand their business and scale of firms. OFDI help the companies to improve efficiency and upgrade production processes. OFDI also help the companies to acquire the knowledge by M\&A, Joint ventures etc. The home economy gets benefitted by the knowledge spillovers to other firms. India have restrictive OFDI framework since liberalization. Although developed countries are the biggest source of Outward Foreign Direct Investment, but transition countries are also emerging as important source of outward investment. Many companies in India are undertaking cross border investment through FDI. Though lot of research has taken place to understand the impact of Outward investment on the economic growth of developed countries, a little research has taken place for developing countries. Policy makers in developing economies are trying to access the impact of outward foreign direct investment on the Gross domestic product through the investment channel. This paper is an attempt in this direction. From a theoretical perspective the impact of outward investment on the domestic economic growth happens from two channels - Financial channel and the production perspective. In an inefficient financial market, an increase of outward foreign direct investment may create a crunch of money supply in the domestic market. This will lead to an increase in the domestic interest rate there by making it difficult for domestic firms to borrow and investment. Thus, it can be said that through the financial market, outward foreign direct investment has a negative impact on the domestic investment and hence is detrimental to the economic growth 
Financial Markets, Institutions and Risks, Volume 3, Issue 1, 2019

ISSN (online) - 2521-1242 ISSN (print) - 2521-1250

of the country. Through the production channel, when firms invest in the production base of foreign countries it reduces the domestic export there by limiting the foreign exchange earnings of the domestic country. However, if companies link their foreign investment to backward and forward linkages in the domestic country, it may increase the export of the country. From this perspective outward investment may be taken as complement to the domestic investment and may have a positive impact on economic growth. Thus, the outward foreign direct investment can have a positive, negative or no impact on the economic growth of the domestic country.

\section{Review of literature}

Pradhan, Prakash J. (2003), examined the role of service sector in OFDI and he explained that recent trends and patterns and tries to identify determinants of such investment. He explained that as compared to 80 's the character of service sector OFDI flows had seen transformations. Whereas in nineties, the software segment has determined the location of OFDI. Pradhan J. P. (2004) examined the factors which determine the economic growth. He found that several firm-specific characteristics such as age, size, R\&D intensity, skill intensity and export orientation are observed to be important explanatory factors in the outward foreign direct investment (OFDI) activity of Indian firms. The impact of age and size on O-FDI has been observed to be non-linear. The product differentiation activities and the productivity of firms are

other useful factors in overseas production expansion in certain industries. Kumar (2007), Pradhan JP (2004) explained the factors of outward FDI using firm-level data. Kumar N. (2007) examined the role of OFDI in the economic growth of India and found that sharp rise in OFDI since 1991 has been accompanied by a shift in the geographical and sectoral focus of Indian investments. Enterprises that are already engaged in exporting are more likely to be outward investors. He also explained that policy liberalization has encouraged Indian enterprises to venture abroad. Saini A., Law S. H., Ahmad A. H. (2010), proved that there is a positive impact of FDI on growth "kicks in" only after financial market development exceeds a threshold level. They have also explained that the benefit of FDI were non-existent before development of financial markets. Hattari and Rajan (2010) explained different choices and motivational factors which determine the location of Indian OFDI.

Singh Y., Bhatnagar A. (2011), compared the role of FDI in China and India's economic growth and found that both enjoys healthy rates of economic growth but FDI inflow in china is higher than India. Agarwal G., Khan M. A. (2011), explain that $1 \%$ increase in FDI would result in $0.07 \%$ increase in GDP of China and $0.02 \%$ increase in GDP of India. Further, he explains that China's growth is more affected by FDI, than India's growth.

Based on the above literature review and other existing literature, it can be explained that most of the research on outward foreign direct investment (OFDI) is based on developed countries. However, in the recent decade even the developing countries have come upon the world map with respect to OFDI. The conclusions drawn from the earlier researches on developed countries may not be applicable to developing countries. Moreover, the effect of OFDI on the domestic economy is not clear. Depending whether OFDI is linked to production or it is regarded as a withdrawal of domestic capital, it can have either positive or negative impact on the GDP of the country. This paper is an attempt to investigate the above gaps.

Data. The study uses annual date on three macro economic variables - Gross Domestic Product at market prices (GDP), Outward foreign direct investment (OFDI) and Gross Capital Formation (GC F) from 20072016. The data on Gross Domestic Product and Gross Capital Formation have been obtained from Handbook of Statistics on Indian Economy available on RBI site while data on OFDI is obtained from various monthly Summary reports of Outward Foreign Direct Investment (OFDI) published by Foreign Exchange DepartmentOverseas investment Division

\section{Research Objective \&Methodology}

The study uses ADF technique to check the stationarity of the data. Co-integration technique is used to explore any long run relationship between the two variables. Finally, regression is used to see the impact of OFDI on the Gross Domestic Product in India.

Augmented Dickey-Fuller (ADF) (Dickey \& Fuller, 1979) is used to check the properties of time series data. These test checks the stationarity of the data. It points out the order of integration of each variable. It helps us to avoid spurious result which may arise if non-stationarity of the data by testing for a stochastic trend. ADFAugmented Dickey fuller Test is used to detect if a variable has a unit root or not. 
1. $\Delta \mathrm{Y}_{\mathrm{t}}=\mathrm{B}_{1}+\mathrm{zY}_{\mathrm{t}-1}+\alpha_{\mathrm{i}}+\mathrm{e}_{\mathrm{t}}$-Intercept only

2. $\Delta \mathrm{Y}_{\mathrm{t}}=\mathrm{B}_{1}+\mathrm{B}_{2 \mathrm{t}}+\mathrm{zY}_{\mathrm{t}-1}+\alpha_{\mathrm{i}}+\mathrm{e}_{\mathrm{t}^{-}}-$Trend and Intercept

3. $\Delta \mathrm{Y}_{\mathrm{t}}=\mathrm{zY} \mathrm{t}-1+\alpha_{\mathrm{i}}+\mathrm{e}_{\mathrm{t}}-$ no trend and no intercept.

Where $Y_{t-1}$ is a macro variable like exchange rate or stock prices. $t$ is a trend variable and $e_{t}$ is a white noise term. The null hypothesis is that variable is non-stationary or has a unit root. $\mathrm{H}_{0}: \rho=1$. The null hypothesis is rejected if the probability is less than $5 \%$. Hence, we accept the alternative hypothesis. The alternative hypothesis is that variable is stationary, or it does not have a unit root. $\mathrm{H}_{0}: \rho \neq 1$.

The study also uses Johansen co-integration technique to study any long run relationship between the two variables. For Johansen co-integration technique the vector auto-regression (VAR) for order $\mathrm{k}$

$$
\Delta \mathbf{x}_{t}=\Pi \mathbf{x}_{t-1}+\sum_{i=1}^{k-1} \Pi_{i} \Delta \mathbf{x}_{t-i}+\mathbf{u}_{t}
$$

The matrix $\Pi$ can be written in terms of the vector or matrix whose rank $r$ determines the number of cointegrating vectors among the variables. Johansen's co-integration test uses maximum likelihood procedure to estimate the $\Pi$ matrix via its eigen values. $\Pi$ can be defined as the product of two matrices:

$\Pi=\alpha \beta$

Where $\alpha=$ vector or matrix of adjustment parameters

$\beta=$ the vector or matrix of co-integrating vectors as

If rank of $(\Pi)=0$ then the variables are not co-integerated and equation 1 is reduced to vector auto regression of first difference.

$$
\Delta \mathbf{x}_{t}=\sum_{i=1}^{k-1} \Pi_{i} \Delta \mathbf{x}_{t-i}+\mathbf{u}_{t}
$$

If the series have a unit root then the number of co-integrating vectors is less than the number of variables. The test uses two test statistics for checking the number of co-integrating vectors- Maximum eigen value statistic $\left(\left(\lambda_{\max }\right)\right.$ and the trace statistic $\left(\lambda_{\text {trace }}\right)$

Maximum Eigen Value test: It is a likelihood ratio test based on maximal eigen value of the stochastic matrix. The test first checks the rank of $(\Pi)$. The null hypothesis of the test is rank of $(\Pi)=0$ while the alternative hypothesis is rank of $(\Pi)=1$.

If the rank of $(\Pi)=0$, then the value of largest eigen value is zero thus no co-integration. If the value of largest eign value $\left(\lambda_{1}\right)$ is non-zero then the rank of the matrice is at least one there by indicating that the variables are co-integrated.

In the second round the next eign value is tested. If second eigen $\left(\lambda_{2}\right)$ is zero then there is exactly one cointegrating vector. On the contrary if $\left(\lambda_{2}\right) \neq 0$ then there are more than two variables that are co-integrated. The procedure continues till the null hypothesis of the eign value being zero cannot be rejected.

The maximum eign value is a likely hood ratio test given by $\operatorname{LR}\left(\mathrm{r}_{0}, \mathrm{r}_{0+1}\right)=-\mathrm{T} \operatorname{In}\left(1-\lambda_{\mathrm{r} 0+1}\right)$

Where $\operatorname{LR}\left(\mathrm{r}_{0, \mathrm{r}_{0+1}}\right)$ is a a like hood ratio statistics for testing the rank of of $(\Pi)=\mathrm{r}$ and alternatively hypothesis rank of of $\left(\prod\right)$ is $r+1$

Trace test - The $\left(\lambda_{\text {trace }}\right)$ Statistics test the null hypothesis $\left(\mathrm{H}_{0}\right)$ rank of $(\Pi)=r$ and the alternative hypothesis $r_{0}$ $<\operatorname{rank}(\Pi) \leq \mathrm{n}$. where $\mathrm{n}$ is the maximum number of possible co-integrations. If the null hypothesis is rejected the next null hypothesis is rank of $(\Pi)=\mathrm{r}_{0}+1$ and the alternative hypothesis is $\mathrm{r}_{0}+1 \quad<$ rank $(\Pi) \leq \mathrm{n}$.

The likely hood ratio test statistic $\operatorname{LR}\left(\mathrm{r}_{0, \mathrm{n}}\right)=-\mathrm{T} \operatorname{In}\left(1-\lambda_{\mathrm{r} 0+1}\right)$, where $\operatorname{LR}(\mathrm{r} 0, \mathrm{n})$ is the likelihood ratio statistic for testing if rank $(\Pi)=r$ versus thealternative hypothesis that rank rank $(\Pi) \leq \mathrm{n}$ 
Financial Markets, Institutions and Risks, Volume 3, Issue 1, 2019

ISSN (online) - 2521-1242 ISSN (print) - 2521-1250

For analyzing the critical values of both the test are studied. If the eigen value statistic and the trace statistics are greater than the critical values, co-integration is present. Also, if the probability is greater than $5 \%$ the null hypothesis - that there is no co-integrating equation is accepted. However, the null hypothesis is rejected if the probability is less than $5 \%$.

The study uses regression analysis where Gross domestic product is taken as a depended variable and Gross Capital Formation along with outward foreign direct investment is the independent variables. Thus, the regression equation in our model is

\section{Gross Domestic Product $=\alpha+\beta$ Gross capital Formation $+\gamma$ Outward Direct Investment}

\section{Data Analysis}

Table1 depicts the trend analysis Gross Domestic Product, Outward foreign direct investment and Gross Capital Formation from 2007-2017. Though gross domestic and Gross Capital formation has constantly been rising but OFDI value is fluctuating. The Outward foreign direct investment was highest in year 2010-11.

Table 1. Trends in Gross Domestic Product, Outward foreign direct investment and Gross Capital Formation

\begin{tabular}{|l|c|c|c|}
\hline Date & GDP & OFDI & GCF \\
\hline $2007-08$ & 49870.9 & 18.4467 & 19007.62 \\
\hline $2008-09$ & 56300.63 & 16.3277 & 19313.8 \\
\hline $2009-10$ & 64778.27 & 12.3036 & 23631.32 \\
\hline $2010-11$ & 77841.15 & 16.4027 & 34030.57 \\
\hline $2011-12$ & 87363.29 & 30.86 & 38471.22 \\
\hline $2012-13$ & 99440.13 & 9.57 & 37941.35 \\
\hline $2013-14$ & 112335.2 & 13.28 & 41797.79 \\
\hline $2014-15$ & 124679.6 & 6.80 & 44423.47 \\
\hline $2015-16$ & 137640.4 & 10.62 & 46714.26 \\
\hline $2016-17$ & 152537.1 & 14.80 & \\
\hline
\end{tabular}

Source: www.rbi.org.in

Table 2. Descriptive analysis

\begin{tabular}{|l|c|c|c|}
\hline & GDP in Million & Gross Capital Formation Million & OFDI in Million \\
\hline Parameter & & & 14.94187 \\
\hline Mean & 96278.67 & 29374.55 & 14.043 \\
\hline Median & 93401.71 & 31222.33 & 30.8629 \\
\hline Maximum & 152537.1 & 44423.47 & 6.80086 \\
\hline Minimum & 49870.9 & 6714.26 & 6.611229 \\
\hline Std. Dev. & 35140.75 & 12086.3 & 1.331901 \\
\hline Skewness & 0.199252 & -0.474361 & 4.526326 \\
\hline Kurtosis & 1.777926 & 2.165906 & 3.927297 \\
\hline & & & 0.140345 \\
\hline Jarque-Bera & 0.688446 & 0.664911 & 149.4187 \\
\hline Probability & 0.708771 & 0.717161 & 393.3752 \\
\hline Sum & 962786.7 & 293745.5 & 10 \\
\hline Sum Sq. Dev. & $1.11 \mathrm{E}+10$ & $1.31 \mathrm{E}+09$ & \\
\hline Observations & 10 & 10 & \\
\hline
\end{tabular}

Source: Researcher analysis from RBI data www.rbi.org.in

Table 1 shows the basis statistics that helps us to define the annual data of Macro economic parameter. Gross domestic product at market price, Gross Capital Formation and Outward Foreign Direct Investment for a period of April 2007-8 to March 2016-17. The descriptive statistics reveal that the average value of Gross Domestic Product period is Rs. 96278.67 million. The highest value that the GDP attained in the given period is Rs 49870.9 million with the lowest of Rs million. The range which is the difference between the maximum and minimum value is 49870.9. This indicates the range between, which Gross domestic Product fluctuates.

Similarly, the average price of Gross Capital Formation is Rs 29374.55 million. The range over which Gross Capital Formation varies is 37,709.21million (44423.47-6714.26). This indicates fluctuations in the Gross Capital Formation.

Descriptive analysis of Outward Foreign Direct Investment reveals a lot of fluctuation. The range is 24.0620 million (30.8629- 6.80086) Skewness measures the symmetrical distribution of the data. 0 Skewness value indicates distribution is normal. The above analysis indicates that variables like - Gross Domestic Product, 
Financial Markets, Institutions and Risks, Volume 3, Issue 1, 2019 ISSN (online) - 2521-1242 ISSN (print) - 2521-1250

Outward Foreign Direct investment are positively skeweed while Gross Capital formation is negatively skeweed. This means there is a greater tendency of of GDP, and OFDI to rise but greater chances that Gross Capital formation will fall.

Table 3. ADF test to check the stationarity of the variables

\begin{tabular}{|c|c|c|c|c|c|c|}
\hline \multicolumn{2}{|c|}{ Level } & \multicolumn{2}{|c|}{ Trend and intercept } & First Diff & Second differ & \\
\hline Adf & T-Statistics & Prob & T-Statistics & Prob & T-Statistics Prob & \\
\hline GDP & -1.466758 & 0.7546 & -11.72031 & 0.0523 & -6.902196 & 0.0108 \\
\hline Gross capital formation & 0.582449 & 0.9965 & -0.247057 & 0.9688 & -5.609462 & 0.0278 \\
\hline OFDI & -2.859592 & 0.2216 & -3.734477 & 0.0865 & -4.62638 & 0.0436 \\
\hline
\end{tabular}

Source: Researcher analysis from RBI data www.rbi.org.in

The above table checks the stationary of the data for all the three series, ADF test reveals that the Macro Economic Indicators - Gross Domestic Product at MP and Gross Capital Formation and Overseas Direct Investment are non stationary at levl and first difference but stationary at second difference.

Table 4. Co-integration

\begin{tabular}{|l|l|l|l|l|}
\hline No. of CE(s) & \multicolumn{1}{|c|}{ Eigenvalue } & \multicolumn{1}{c|}{ Statistic } & Critical Value & Prob \\
\hline None & 0.760545 & 14.58532 & 15.49471 & 0.0682 \\
\hline At most 1 & 0.325495 & 3.150207 & 3.841466 & 0.0759 \\
\hline
\end{tabular}

Source: Researcher analysis from RBI data www.rbi.org.in

In the above table the eigen value is less than the critical value thus the analysis documents no long run relationship between Outward foreign direct investment and economic growth. Similar results are obtained through the trace statistics and can be confirmed through the probability value.

Table 5. Regression

\begin{tabular}{|l|c|c|c|c|}
\hline \multicolumn{1}{|c|}{ Variable } & Coefficient & Std. Error & T-Statistic & Prob. \\
\hline C & 0.125943 & 0.009517 & 13.23323 & 0 \\
\hline RETURNGROSS Capital Formation & 0.014462 & 0.015183 & 0.952504 & 0.04376 \\
\hline RETURNOFDI & 0.002123 & 0.017157 & 0.12373 & 0.9056 \\
\hline R-Squared & 0.42256 & & & \\
\hline Adjusted R-Squared & -0.156586 & & & \\
\hline S.E. Of Regression & 0.027979 & & & \\
\hline Sum Squared Resid & 0.004697 & & & \\
\hline Log Likelihood & 21.24092 & & & \\
\hline F-Statistic & 0.458454 & & & \\
\hline Prob(F-Statistic) & 0.652706 & & & \\
\hline
\end{tabular}

Source: Researcher analysis from RBI data www.rbi.org.in.

Table 5, documents the regression analysis GDP at MP on two dependent variables Gross Capital Formation and OFDI. Please note Gross Domestic Capital Formation has a positive relation with Gross Domestic Product. Thus, Higher Gross Capital Formation higher is the GDP. However, OFDI impact on GDP is not signification. Thus, empirical data do not support relationship of Outward foreign direct investment to Gross Domestic product. This is in contradiction to earlier researches which documented positive results for developed countries. This indicates that no backward or forward linkages are created in the domestic country. Thus, there is no increment in the country's export. At the same time outward foreign direct investment is not considered as withdrawal of funds from the domestic market. There is enough liquidity in the Indian economy to increase the interest rate. Thus, empirically no evidence was found between the two variables. Many economists argue that in India outward foreign direct investment is not a true investment happening in foreign countries. Companies get into money laundering by invest their money in tax haven countries and re-investing in the domestic country. Thus, no actual production happens in foreign country as a result no linkages are developed.

\section{Conclusion}

This study provides new empirical evidence of the effects of outward FDI on the Gross Domestic Product rate in India. While most of the researchers focus on effects of developed countries outward FDI on their own domestic economic activity but very few attempts have been made to study the above variables in the transition economies. Our paper is an attempt in this direction. The impact of outward foreign direct investment on the home economy depends upon the motive of investing abroad. The researcher contemplates that most of the outward foreign direct investment from India do not lead to any significant production in the foreign country 
Financial Markets, Institutions and Risks, Volume 3, Issue 1, 2019

ISSN (online) - 2521-1242 ISSN (print) - 2521-1250

rather it finds its way back in the home country through the countries which are said to be the tax havens of the world. Thus, no empirical evidence has been found which can conclude that there is a linkage between Outward Foreign Direct investment (OFDI) and domestic economic growth in India. There are some intuitive reasons for this may be that Indian companies which send OFDI may not be using it for any productive purposes or it may not have any spillover effect on the domestic companies. So, it can be concluded that there is no significant linkage between the OFDI and domestic economic growth. It is further suggested that Indian government may give various incentives to the companies. So, that OFDI may bring back some benefits to India.

\section{References}

1. Adams, S. (2009). Foreign direct investment, domestic investment, and economic growth in Sub-Saharan Africa. J. Policy Model. 31, 939-949.

2. Anwar, S. Nguyen, L.P. (2010). Foreign direct investment and economic growth in Vietnam. Asia Pac. Bus. Rev. 16, 83-202.

3. Agarwal G., Khan M. A. (2011). Impact of FDI on GDP: A Comparative Study of China and India. International Journal of Business and Management, 6(10).

4. Al-Sadig, Ali. J. (2013). Outward Foreign Direct Investment and Domestic Investment: The Case of Developing Countries, IMF Working Paper, WP/13/52, Washington DC.

5. Bengoa, M., Sanchez-Robles, B., (2005). FDI, economic freedom, and growth: new evidence from Latin America. Eur. J. Polit. Econ. 19, 529-545.

6. Borensztein, J., De Gregorio, J., Lee, J.W. (1998). How does foreign direct investment affect economic growth? J. Int. Econ. 45, 115-135.

7. Chipalkatti N., Rishi M. (2001). External Debt and Capital Flight in the Indian Economy Oxford Development Studies, 29(1).

8. Das, K. C. (2013). Outward FDI and its Effect on Domestic Activities- An Examination of Indian Manufacturing Firms, Institute for Financial Management and Research (IFMR), Chennai.

9. Deng, P (2004). Outward investment by Chinese MNCs: Motivations and implications, Business Horizons, Elsevier, 47(3), 8-16.

10. Dickey, D.A. and Fuller, W.A. (1979). Distribution of the estimators for autoregressive time series with a unit root, Journal of the American Statistical Association, 74, 427-31.

11. Elia, S., Mariotti, I., Piscitello, L. (2009). The impact of outward FDI on the home country's labour demand and skill composition, Elsevier, International Business Review 18

12. Goldar, B. (2013). Direction of Outward FDI of Indian Manufacturing Firms: Influence of Technology and Firm Productivity, VIII Annual International Conference on Emerging Technologies and Development, IIT Bombay, Mumbai, India.

13. Herzer, D. (2008). The Long-run Relationship between Outward FDI and Domestic Output: Evidence from Panel Data, Economics Letters, 100, 1.

14. Herzer, D. (2011). The Long-run Effect of Outward FDI on Domestic Output in Developing Countries, Applied Economic Letters, 18(14).

15. Herzer, D. (2012). Outward FDI, Total Factor Productivity and Domestic Output: Evidence from Germany, International Economic Journal, 26(1).

16. Johansen, J. (1988). Statistical Analysis of Cointegration Vectors. Journal of Economic Dynamics and Control 12, 231-254.

17. Kumar N. (2007). Emerging TNCs: trends, patterns and determinants of outward FDI by Indian enterprises, Transnational Corporations, 16(1), (April 2007)

18. Lee, C. G. (2010). Outward Foreign Direct Investment and Economic Growth: Evidence from Japan, Global Economic Review, 39(3). 
19. Levin, A., Lin, C. F., \& Chu, C. S. J. (2002). Unit root tests in panel data: asymptotic and finite-sample properties. Journal of econometrics, 108(1), 1-24.

20. Lim, M. E. G. (2001). Determinants of, and the relation between, foreign direct investment and growth: a summary of the recent literature (1-175). International Monetary Fund.

21. Liu, X., Burridge, P., \& Sinclair, P. J. (2002). Relationships between economic growth, foreign direct investment and trade: evidence from China. Applied economics, 34(11), 1433-1440.

22. Neil, F. \& Anders, I and Floria, K., (2014). Outward Foreign Direct Investment, Exporting and FirmLevel Performance in Sub-Saharan Africa, Journal of Development Studies, Taylor \& Francis Journals, 50(2), 244-257.

23. Pesaran, M. H., \& Shin, Y. (1998). An autoregressive distributed-lag modelling approach to cointegration analysis. Econometric Society Monographs, 31, 371-413

24. Pradhan, J. P. (2004). The Determinants of Outward Foreign Direct Investment: A firm level Analysis of Indian Manufacturing, Oxford Development Studies, 32, 619-639.

25. Pradhan, J. P. (2008). The Evolution of Indian Outward Foreign Direct Investment: Changing Tends and Patterns, International Journal of Technology and Globalisation, 4, 70-86.

26. Pradhan, J. P. and V. Abraham (2005). Overseas Mergers and Acquisitions by Indian Enterprises: Patterns and Motivations, Indian Journal of Economics, 85, 365-386.

27. Saini A., Law S. H., Ahmad A. H. (2010). FDI and economic growth: New evidence on the role of financial markets, Economics Letters, 107(2), 211-213.

28. Sauramo, P. (2008). Does Outward Foreign Direct Investment Reduce Domestic Investment? MacroEvidence from Finland, Labour Institute for Economic Research, Discussion Paper, 239, Helsinki.

29. Singh, Neelam (2007). Automotive Industry' in N. Kumar and K.J. Joseph (eds.) International Competitiveness \& Knowledge-based Industries in India, 233-279, New Delhi: Oxford University Press.

30. Singh, Y, and Bhatnagar.A (2011). FDI in India and China; A comparative analysis, International Journal of Business Economics and Management Research, 2(4), 139-153.

31. Stevens, G. V., \& Lipsey, R. E. (1992). Interactions between domestic and foreign investment. Journal of international money and finance, 11(1), 40-62.

32. Tang, S., Selvanathan, E., Selvanathan, S. (2008). Foreign direct investment, domestic investment and economic growth in China: a time series analysis. World Econ. 31, 1292-1309.

33. Thomas, R. and Narayanan, K. (2013). Outward FDI, Firm Heterogeneity and Technological Efforts: A study of Indian Manufacturing, VIII Annual International Conference on Emerging Technologies and Development, IIT Bombay, Mumbai, India.

34. Zhao, W., Liu, L. and Zhao, T. (2010). The Contribution of Outward Direct Investment to Productivity Changes within China, 1991-2007, Journal of International Management, 16(2). 